\title{
Assessment of Dissolved Ions and Microbial Coliform in Water from Selected Sites of the Upper Athi River Sub-Catchment Area, Kenya.
}

\author{
Muraga $\mathrm{JM}^{1}$, Wandiga $\mathrm{SO}^{1}$, Abong'o DA ${ }^{1}$ \\ ${ }^{I}$ College of Biological and Physical Sciences, School of Physical Science, Department of Chemistry, University \\ of Nairobi, P.O. Box 30197-00100, Nairobi, Kenya.
}

\begin{abstract}
Twenty one water samples were collected and analysed for dissoved ions and microbial coliforms from selected sites of the Upper Athi River sub-catchment basin. The metal ions analysed included $\mathrm{Ca}, \mathrm{Cd}, \mathrm{Cr}$, $\mathrm{Cu}, \mathrm{Fe}, \mathrm{Mg}, \mathrm{Mn}, \mathrm{Na}, \mathrm{Pb}$ and $\mathrm{Zn}$ while anions included $\mathrm{Cl}, \mathrm{CO}_{3}{ }^{2-} / \mathrm{HCO}_{3}^{-}, \mathrm{F}, \mathrm{NO}_{2}{ }^{-} / \mathrm{NO}_{3}^{-}$and $\mathrm{SO}_{4}{ }^{2-}$ as well as faecal coliforms. Physical parameters analysed included pH, electrical conductivity (EC) turbidity, total dissolved solids and colour. The analysis was carried out using atomic absorption spectrophotometry, titrimetric, ion selective electrode, gravimetric and lactose broth methods. The results showed that levels of dissolved ions in ground water were higher than in surface water while surface water had higher number of faecal coliforms. The high levels of dissolved ions in ground water was attributed to the geology of area while high levels of iron and faecal coliforms in river water samples was attributed to anthropogenic activities
\end{abstract}

Keywords: Anions, coliforms, ground water, heavy metals, Upper Athi

\section{Introduction}

Clean and safe drinking water is vital to health as well as a basic constitutional right [1]. Safe drinking water is one that does not contain disease- causing micro-organisms, or toxic heavy metals that could cause bioaccumulation when such water is used over a long duration of time. Children and the elderly are particularly the most vulnerable groups from effects of using unsafe drinking water [2]. There is increasing demand for safe drinking water as the world population continues to increase in the backdrop of inadequate fresh drinkable water in many parts of the world[3]. For meaningful prosperity to be realized clean and safe drinking water that is readily available should be the point of focus by governments and local authorities according to water quality assessment of 2007 by the Ministry of Water and irrigation [2].

Sustaining sufficient water supplies for domestic, agricultural and industrial use would be impossible without groundwater which is the largest and most reliable of all freshwater resources since it is being used by about two billion people worldwide; making it the most important natural resource [2].By estimates the world is producing between 9087 billion $\mathrm{m}^{3}$ of water annually [4]. Kenya in particular faces acute water shortage both in urban and many rural areas. Of particular concern is the ever growing urban population especially in Nairobi [5]. Several up-coming residential areas around Nairobi are not supplied with safe drinking water from the licensed water companies [5]. This has forced residents of these areas to explore other possibilities such as digging shallow wells and drilling bore-holes in order to access water for domestic purpose [5]. Whereas ground water has become a panacea to many families, institutions and companies, its suitability has not been ascertained. Comprehensive studies in several areas of Athi basin in Kenya (see fig.1) have not been done to establish whether the groundwater meets the safety standards for human and animal consumption. Therefore, human population in areas whose ground water quality is not known faces a risk of illness such as osteomalacia and fluorosis caused by high levels of dissolved ions [6]. This study was therefore to assess the residue levels of various cations, anions and coliform bacteria in ground and surface waters in selected areas of upper Athi River basin and compare them with world health organization (WHO) and Kenya bureau of standard (KEBS) specifications levels for drinking water.

\subsection{The Study Area}

\section{Materials And Methods}

The study area (Figure 1) is located in the East-Southeast of Kenya and lies between latitude $1^{\circ} 15^{\prime}$ to $1^{\circ} 30^{\prime} \mathrm{S}$ and longitude $36^{\circ} 39^{\prime}$ to $37^{\circ} 05^{\prime} \mathrm{E}$. The area stretches about $45 \mathrm{~km}$ along the Upper Athi Sub-catchment area. The area is rapidly growing in terms of human population and therefore ground water in form of shallow wells and boreholes has become an essential natural resource for domestic, industrial and agricultural and livestock use [[7]. 


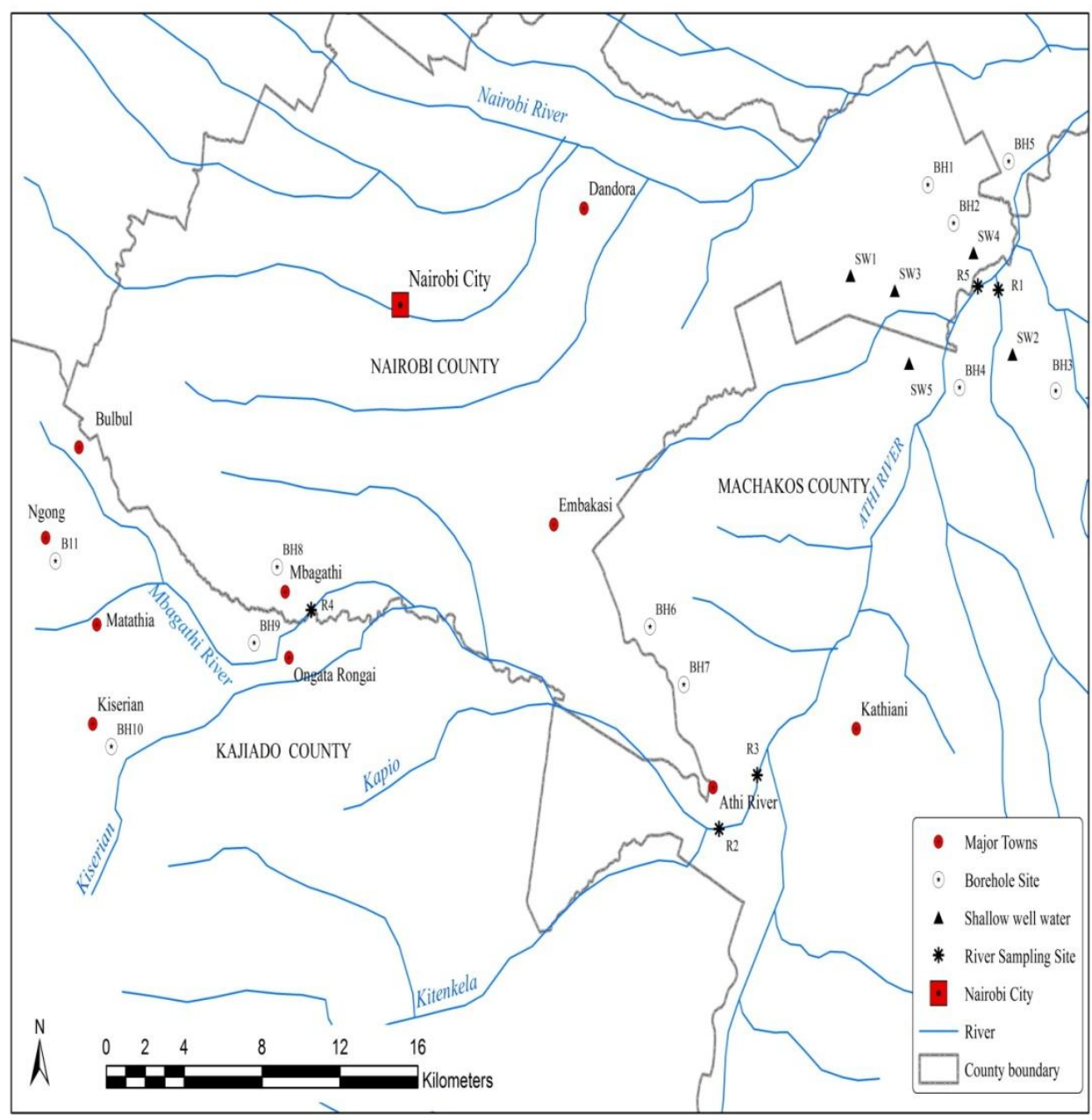

Figure 1: Map of Upper Athi River sub-catchment area showing sampling sites.

\subsection{Sample collection}

Twenty one samples of water were collected from selected sites ranging from boreholes, shallow wells and river using pre-cleaned polyethylene bottles. The samples were taken to the Department of Chemistry's laboratory at the University of Nairobi for analysis. Samples were collected intwo seasons, in the December 2011 (dry) and May 2012 (wet). This was mainly to find theseasonal variation and human activities on the residue levels ofphysico-chemical parameters, dissolved ions and the number of coliform presentin the water samples.

\subsection{Sample Preparation and Analysis}

The water samples were acid digested following methods by [5] and [6]. To each beaker, $25 \mathrm{ml}$ of $10 \%$ hydrochloric acid $(2.50 \mathrm{ml}$ Concentrated acid $+22.50 \mathrm{ml}$ deionized water) was added. The contents were filtered through the Whitman filter paper No. 1 and filtrate collected in a $250 \mathrm{ml}$ beaker. The residue in the filter paper was washed 4 times with $50 \mathrm{ml}$ hot deionized water, the washings collected with the $250 \mathrm{ml}$ beaker and allowed to completely cool. The solution in the $250 \mathrm{ml}$ beaker was transferred into correspondingly labelled 250 $\mathrm{ml}$ volumetric flasks. The beaker was rinsed and volume of the solution in the $250 \mathrm{ml}$ volumetric flask made to the mark with the deionized water.

\subsubsection{Analysis of chloride.}

$200 \mathrm{ml}$ of the water sample was transfered into a $400 \mathrm{ml}$ beaker. $5 \mathrm{ml}$ of concentrated nitiric acid was added to neutralize calcium carbonate until no reaction further occurred. The solution was boiled for 5 mimutes and then filtered through Whiteman filter paper No.1 $(150 \mathrm{~mm}) .100 \mathrm{ml}$ of the solution was pippeted in a porcelain dish. $1 \mathrm{ml}$ ofpotassium dichromate $\left(\mathrm{K}_{2} \mathrm{CrO}_{4}\right)$ indicator solution was added and well mixed. The solution was then titrated against $\mathrm{N} / 10$ silver nitrate $\left(\mathrm{AgNO}_{3}\right)$ solution until the colour changed from yellow to brown. The readings of silver nitrate was recorded as procedure was repeated twice to obtain consistent results for all the samples. 
Calculations

Chloride as $\mathrm{Cl}$ ppm $=\left(\mathrm{ml} \mathrm{AgNO}_{3}\right.$ sample- $\mathrm{ml} \mathrm{AgNO}_{3}$ blank $)$ x normality of $\mathrm{AgNO}_{3} \times 10 \times 35.5$

\subsubsection{Potentiometric determination of fluorides}

The fluoride was determined potentiometrically using a Fluoride ion meter by dipping the fluoride electrode meter into $50 \mathrm{ml}$ of the sample and taking the levels of fluoride in the sample the analysis wascarried out at the Central water testing laboratory, at the Ministry of Water

\subsubsection{Determination of total alkalinity of carbonate and bicarbonate using Titration method}

$100 \mathrm{ml}$ of the watersample was measured and transfered into a porcelain boat. 2 drops of phenolphathein indicator was added. The mixture was titrated slowly using $0.1 \mathrm{~N}$ hydrochoric acid $(\mathrm{HCl})$ while stirring gently with a glass rod until the colour just disappeared. The volume of the acid used was recorded. To the same sample, 2 drops of methyl orange indicator was added. The sample was further titrated slowly using $0.1 \mathrm{~N} \mathrm{HCl}$ till colour change from yellow was noted. The total volume of the acid used was recorded and the the procedure was repeated twice for consistencefor all the samples.

Calculations

Alkalinity to phenolphthalein as mg/ $1 \mathrm{ml} 9 \mathrm{ppm}) \mathrm{CaCO}_{3}=\mathrm{X}(\mathrm{ml}$ of $\mathrm{N} / 10 \mathrm{HCl}) \times 5 \quad \mathrm{x} 1000$ $\mathrm{ml}$ of the sample taken $\left(1 \mathrm{ml} \mathrm{N} / 10 \mathrm{HCl} \equiv 5 \mathrm{mg} \mathrm{CaCO}_{3}\right)$

Alkalinity to methyl orange $\mathrm{mg} / \mathrm{l}(\mathrm{ppm}) \mathrm{CaCO}_{3}$

$=\mathrm{Y}(\mathrm{ml}$ of $\mathrm{N} / 10 \mathrm{HCl}) \times 5 \times 1000 \mathrm{ml}$ of the sample taken

Total alkalinity $=$ alkalinity to phenolphthalein + alkalinity to methyl orange

\subsubsection{Gravimetric determination of sulphate ions}

$100 \mathrm{ml}$ of water sample was pippeted into $250 \mathrm{ml}$ beaker and $2 \mathrm{ml} \mathrm{1:1} \mathrm{HCl}$ was added. The mixture was boiled while adding an excess $10 \%\left(10 \mathrm{~g} \mathrm{BaCl}_{2} \cdot 2 \mathrm{H}_{2} \mathrm{O}\right.$ in $100 \mathrm{ml}$ distilled water)solution slowly while stirring. The precipitate was digested for 2 hours at $80^{\circ} \mathrm{C}$ on the hot plate. The precipitate was then filtered through Whitmanfilter paper No. 542 and wash with warmed distilled water till free from chloride(tested with $\mathrm{AgNO}_{3}$ solution). The residue was dried and ignited at $800^{\circ} \mathrm{C}$ to constant weight and the the procedure was repeated for all the samples.

Calculating the Sulphate content; $\mathrm{SO}_{4}{ }^{2-} \mathrm{ppm}=$ weight of residue in $\mathrm{mg} \times 0.4115 \times 10$

\subsubsection{Analysis of metal ions using atomic absorption spectrameter}

Analysis of metal ions was done using atomic absorption spectrophotometer, (Model AAS Varian spectra AA 10) at Mines and Geology Department. $100 \mathrm{ml}$ of water sample was measured using a $100 \mathrm{ml}$ volumetric flask and then transfered into a $250 \mathrm{ml}$ conical flask. $10 \mathrm{ml}$ of concentrated nitric acid was added into the flask and stirred. The mixture was then digested at $80^{\circ} \mathrm{C}$ for two hours. The solution was then filtered through Whatman filter paper No.1 into a $100 \mathrm{ml}$ volumetric flask and filled to the mark using distilled deionizedwater.

\subsubsection{Analysis of Nitrates}

Presence of nitrates in water samples were determined by preparing standards, that is, $0.01 \mathrm{ppm}$ to $20 \mathrm{ppm}$ from 100ppm stock potassiumnitrate solution. The standards were then transferred into a beaker and $1 \mathrm{ml}$ of nitrate buffer $\left(\mathrm{NH}_{4}\right) \mathrm{SO}_{4}$ was added. The nitrate electrode was inserted into the beaker starting with the lowest standard. Then, $50 \mathrm{ml}$ of the sample was put into a beaker and $1 \mathrm{ml}$ of buffer added. The nitrate electrode meter was inserted into the solution and the concentration was measured.

For nitrites, the formation a reddish azo dye at $\mathrm{pH}$ 2.0-2.5 was determined by coupling diazotized sulfanilamide with $\mathrm{N}$-(1 naphthyl)ethyldiaminedihydrochloride (NED dihydrochloride).To 50ml of the sample, $2 \mathrm{ml}$ of colour reagent was added and mixed thoroughly. Any colour change was noted as an indication of presence of nitrite ions.

\subsubsection{Analysis of total coliform and Escherichia Coliform (E. coli)}

Total coliforms and Escherichia Coliform(E.coli) were analyzedby inoculating a $50 \mathrm{ml}$ water sample and five $10 \mathrm{ml}$ samples in lactose broth for 48 hours at $35^{\circ} \mathrm{C}$ or $37^{\circ} \mathrm{C}$ total coliform and 24 hours at $44^{\circ} \mathrm{C}$ for thermo tolerant coliform and the MPN index value was determined from specific tables to the combination of tubes and dilutions.

\subsection{Statistical Data Analysis}

Data analysis was done using Microsoft excel,the correlations between the seasonal variation and the level of selected cations, anions and feacal coliforms were done using Statistical Package for Social Sciences tools (SPSS). Results obtained was represented by use of text, graphs and statistical tables to show the 
interrelationships of various variables such as $\mathrm{pH}$, TDS, electrical conductivity (EC),turbidity, levels of selected cations, anions and Feacal coliforms in boreholes, shallow wells and river water samples.

\section{Results And Discussions}

\subsection{Physicochemical parameters and anions in water samples of Upper Athi catchment area.}

The physicochemical parameters, $\mathrm{pH}$, electrical conductivity (EC), turbidity, colour, TDS, coliforms and anions in water samples of Upper Athi Rivercatchment collected in December 2011 are shown in Table 1. The $\mathrm{pH}$ varies from 7.24 to 9.34 with an average of 8.04 . The $\mathrm{pH}$ is slightly neutral to weakly alkaline. The $\mathrm{pH}$ could be attributed to rocks in the study area that include the alkali-basalt, syenite and phonolites that have high concentration calcite minerals rich in carbonate ions [8].

Table 1: Physico-chemical and biological parameters in water samples from the shallow wells, boreholes and rivers in the upper Athi River catchment in December 2011.

\begin{tabular}{|c|c|c|c|c|c|c|c|c|c|c|c|}
\hline \multirow{2}{*}{$\begin{array}{l}\text { Sites } \\
\text { SW1 }\end{array}$} & \multirow{2}{*}{$\frac{\overline{\mathrm{pH}}}{\mathrm{8.24}}$} & \multirow{2}{*}{$\begin{array}{l}\text { E.C } \\
813\end{array}$} & \multicolumn{2}{|c|}{ Turbidity Colour } & \multirow{2}{*}{$\begin{array}{c}\text { TDS } \\
504.26\end{array}$} & \multicolumn{3}{|c|}{$\begin{array}{c}\text { Coliforms } \text { TotalCl }^{-} \\
\text {Alkalinity }\end{array}$} & \multirow{2}{*}{$\begin{array}{r}\mathrm{F}^{-} \\
1.67\end{array}$} & \multirow{2}{*}{$\frac{\mathrm{NO}_{3}^{-}}{2.98}$} & \multirow{2}{*}{$\frac{\mathrm{SO}_{4}{ }^{2-}}{36.14}$} \\
\hline & & & $\overline{B D L}$ & 1.70 & & 0.00 & 56.41 & 74.11 & & & \\
\hline SW2 & 7.81 & 805 & BDL & 1.60 & 499.18 & 0.00 & 43.69 & 65.91 & 2.85 & 3.01 & 75.68 \\
\hline SW3 & 8.47 & 832 & BDL & 1.90 & 516.63 & 25.00 & 30.11 & 226.49 & 4.26 & 13.45 & 230.76 \\
\hline SW4 & 8.16 & 669 & BDL & 1.50 & 415.48 & 0.00 & 36.24 & 96.38 & 3.94 & 8.62 & 41.40 \\
\hline SW5 & 9.34 & 943 & BDL & 2.70 & 585.79 & 0.00 & 43.65 & 101.27 & 4.32 & 4.73 & 38.57 \\
\hline BH1 & 8.49 & 794 & BDL & 0.00 & 508.16 & 0.00 & 52.33 & 111.75 & 4.24 & 2.84 & 69.23 \\
\hline $\mathrm{BH} 2$ & 7.54 & 891 & BDL & 0.00 & 570.24 & 0.00 & 50.65 & 109.23 & 2.45 & 3.05 & 74.65 \\
\hline $\mathrm{BH} 3$ & 7.78 & 758 & BDL & 0.00 & 485.12 & 0.00 & 48.42 & 70.84 & 3.96 & 2.13 & 101.14 \\
\hline BH4 & 8.59 & 840 & BDL & 2.70 & 521.35 & 0.00 & 31.73 & 106.56 & 4.02 & 3.29 & 21.40 \\
\hline BH5 & 9.34 & 943 & 13.6 & 46.50 & 585.81 & 0.00 & 64.12 & 96.42 & 4.51 & 1.86 & 65.61 \\
\hline BH6 & 8.65 & 975 & BDL & 3.20 & 605.64 & 0.00 & 38.98 & 138.58 & 9.36 & 1.77 & 140.80 \\
\hline BH7 & 8.47 & 1000 & BDL & 1.20 & 620.76 & 0.00 & 40.44 & 150.11 & 8.79 & 5.01 & 155.34 \\
\hline BH8 & 7.93 & 449 & BDL & 0.00 & 278.92 & 0.00 & 35.63 & 43.29 & 2.06 & 9.68 & 17.30 \\
\hline BH9 & 7.28 & 362 & BDL & 6.80 & 224.92 & 0.00 & 37.42 & 89.14 & 0.37 & 8.32 & 15.11 \\
\hline BH10 & 8.23 & 440 & BDL & 1.40 & 273.59 & 0.00 & 29.66 & 30.04 & 3.11 & 2.11 & 19.72 \\
\hline BH11 & 7.75 & 743 & BDL & 0.30 & 461 & 0.00 & 41.57 & 99.18 & 1.01 & 5.98 & 43.836 \\
\hline $\mathrm{R} 1$ & 7.32 & 647 & 81.60 & 226 & 401.24 & 140 & 8.21 & 33.10 & 0.73 & 7.39 & 506.24 \\
\hline $\mathrm{R} 2$ & 7.47 & 516 & 79.40 & 256 & 320.38 & 215 & 20.65 & 107.60 & 0.91 & 3.54 & 80.12 \\
\hline R3 & 7.43 & 463 & 84.40 & 219 & 287.45 & 294 & 21.02 & 120.30 & 1.02 & 3.92 & 74.74 \\
\hline $\mathrm{R} 4$ & 7.33 & 382 & 75.50 & 159 & 237.62 & 193 & 25.94 & 89.40 & 3.15 & 15.68 & 83.05 \\
\hline $\mathrm{R} 5$ & 7.24 & 752 & 74.30 & 198 & 462.71 & 193 & 10.73 & 90.53 & 1.37 & 11.36 & 520.32 \\
\hline Min. & 7.24 & 362 & BDL & 0.00 & 224.92 & 0.00 & 8.21 & 33.1 & 0.37 & 1.77 & 15.11 \\
\hline Max & 9.34 & 1000 & 84.40 & 256 & 620.76 & 294 & 64.12 & 226.49 & 9.36 & 15.68 & 520.32 \\
\hline Mean & 8.04 & 715 & 68.50 & 53.78 & 436.37 & 50.48 & 35.55 & 97.63 & 3.24 & 5.748 & 114.81 \\
\hline SD & 0.63 & 204.05 & 26.97 & 92.34 & 150.54 & 92.24 & 14.28 & 42.56 & 2.37 & 4.040 & 142.25 \\
\hline
\end{tabular}

SW: Shallow wells, BH: Boreholes, R: River water, below detection limit (BDL)

Electrical conductivity ranged from 362 to $1000 \mu \mathrm{S} / \mathrm{cm}$ in water samples collected in December 2011 (Table 1).Electrical conductivity is dependent on the type of rocks the water is in contact with and how long it takes for water to percolate into the underground aquifer [9]. Rain water which is the main source of underground water is slightly acidic and therefore tends to react with feldspar minerals mainly consisting of potassium, sodium and aluminum silicates [10]. These tend to increase levels of dissolved ions in ground water more that of surface water[11]. Underground water had turbidity levels of below detection limit except in borehole 5 (BH5) that had turbidity values of 13.6-18.4 NTU while surface water had turbidity levels of between 74.3-95.4 NTU(Table 1). The low turbidity levels in underground water is attributed to the fact that silt sand and mud are trapped by the overlying rocks which act as a sieve such that by the time water percolates into the aquifer underground, there in insignificant levels of suspended solid particles [12]. On the other hand, surface water had higher values of turbidity due to surface run-offs that carry silt and organic matter into the streams and rivers [13]. According to WHO drinking water guidelines, drinking water should have turbidity levels of below 5 NTU [14].

The colour for underground water systems were very low, ranging from0-6-6.8 c.u apart from borehole 5 (Table 1) which had colour levels of between 46.5-51.2 c.u. Surface water on the other hand had higher colour 
levels ranging from 159-343 c.u. Total dissolved solids were high in both underground and surface water in the samples collected which ranged from 224.92-620.76 $\mathrm{S} / \mathrm{cm}$ during the dry season of December 2011 and 302.8 $1003 \mu \mathrm{S} / \mathrm{cm}$ during the wet season of May 2012 (Table 2). The high levels of total dissolved solids (TDS) were attributed to the geology of the area of study that had high levels of sodium, calcium, carbonates and Sulphates [15]. TheWHO water drinking standards require that water which is deemed safe for drinking should have TDS levels of less than $500 \mathrm{mg} / \mathrm{L}[15]$. TDS levels above this limit make water unpalatable and has potential of being contaminated with heavy metals such as copper, iron, cadmium, lead and zinc [16].

Total coliforms were generally low in underground water ranging from 0-25 c.f.u/100ml of water in dry season of December 2011. Shallow wells had slightly higher total coliforms that the boreholes pointing to possible anthropogenic effect and the sheer depth of the shallow wells which could lead to contamination from pit latrines nearby as well as contamination from animal manure that tend to be transported to streams and rivers by surface run-offs [17].

Total alkalinity was higher in underground water compared to surface water ranging from 30.11$64.117 \mathrm{ppm}$ in dry season and $25.0057 .50 \mathrm{ppm}$ during the wet season of May 2012 while in surface water total alkalinity ranged from 6.50-25.94ppm [18] [19]. The high levels of carbonates and hydrogen carbonates was attributed to presence of carbonaceous shale in the area of study.Chloride levels were high in both underground water and surface ranging from 33.10-226.49ppm in December 2011 and 26.03-145.55ppm in May 2012. Whereas the high levels of chloride ions in underground water could be attributed to the geology of the study area, the high levels of chloride ions in surface water was astonishing pointing at a possible anthropogenic activities from point source pollution such as abattoirs that lead to high levels of chlorides finding their way into rivers and streams [20].Chloride levels in unpolluted water systems ranges from $250 \mathrm{mg} / \mathrm{L}$. Chloride levels above this limit make water to have a detectable taste[21]. Fluoride levels were higher in underground water compared to surface water which ranged from 0.37-9.36ppm in December 2011 and 7.00ppm in May 2012. In most underground water sites sampled, fluoride levels were higher than those recommended by WHO of $1.5 \mathrm{ppm}$ in water for human consumption [22]. It is therefore evident that communities living in these areas where the only source of water is underground water, they are consuming water that is unfit for human consumption. Whereas fluoride levels at low concentrations is essential in the formation of enamel in children, studies have shown that daily intake of fluoride at concentration above $0.5 \mathrm{mg} / \mathrm{L}$ could lead to mild dental fluorosis in children. Intake of fluoride at concentrations above $2.0 \mathrm{mg} / \mathrm{L}$ could lead to severe skeletal effects [22]. Nitrates levels were higher in surface water samples as compared to underground water samples. The high levels of nitrates in surface water could be due to inorganic nitrate fertilizers or from contamination from human and animal wastes as a result of oxidation of ammonia by anaerobic bacteria and find their way in into waterways through surface run-offs [23]. Sulphate levels were higher in surface water than in underground water with levels ranging from 74.735-520.321 ppm and 15.11-230.763ppm respectively. The high levels of sulphates in surface water could be attributed to human activities especially from sulphonates containing detergents and industrial effluents. Whereas there is no known health risk associated with high intake of sulphates, it is recommended that drinking water should not exceed $500 \mathrm{mg} / \mathrm{L}$ of sulphate it would increase the risk of gastrointestinal effects such as diarrhea [24].

Table 2. Physico-chemical and biological parameters in water samples from shallow wells, boreholes and rivers in the upper Athi River catchment in May 2012.

\begin{tabular}{|c|c|c|c|c|c|c|c|c|c|c|c|}
\hline \multirow{2}{*}{$\begin{array}{l}\text { Sites } \\
\text { SW1 }\end{array}$} & \multirow{2}{*}{$\begin{array}{c}\mathrm{pH} \\
7.72\end{array}$} & \multirow{2}{*}{$\begin{array}{l}\text { E.C } \\
502\end{array}$} & \multicolumn{2}{|c|}{ Turbidity Colour } & \multirow{2}{*}{$\begin{array}{c}\text { TDS } \\
321.28\end{array}$} & \multicolumn{3}{|c|}{$\begin{array}{r}\text { Coliforms Total } \\
\text { Alkalinity }\end{array}$} & \multirow{2}{*}{$\begin{array}{r}\mathrm{F}^{-} \\
1.52\end{array}$} & \multirow{2}{*}{$\frac{\mathrm{NO}_{3}^{-}}{1.89}$} & \multirow{2}{*}{$\frac{\mathrm{SO}_{4}{ }^{2-}}{29.22}$} \\
\hline & & & BDL & 2.10 & & 10.00 & 39.00 & 67.45 & & & \\
\hline SW2 & 7.16 & 938 & BDL & 1.70 & 600.28 & 16.00 & 37.50 & 56.80 & 2.06 & 2.71 & 69.54 \\
\hline SW3 & 7.36 & 1568 & $\mathrm{BDL}$ & 2.00 & 1003.00 & 40.00 & 26.30 & 216.55 & 4.06 & 12.32 & 214.80 \\
\hline SW4 & 8.45 & 635 & BDL & 1.60 & 406.20 & 12.00 & 30.20 & 89.93 & 3.75 & 6.78 & 34.98 \\
\hline SW5 & 8.06 & 913 & BDL & 3.20 & 584.32 & 18.00 & 37.50 & 92.30 & 4.18 & 2.52 & 28.81 \\
\hline BH1 & 8.14 & 1001 & BDL & 2.10 & 640.64 & 25.00 & 45.00 & 102.95 & 3.87 & 2.20 & 60.49 \\
\hline $\mathrm{BH} 2$ & 8.03 & 1118 & BDL & 1.50 & 715.52 & 0.00 & 42.50 & 100.56 & 2.09 & 2.21 & 69.13 \\
\hline $\mathrm{BH} 3$ & 7.27 & 1154 & BDL & 2.60 & 738.00 & 0.00 & 41.50 & 67.45 & 2.76 & 1.53 & 91.35 \\
\hline $\mathrm{BH} 4$ & 7.34 & 1271 & BDL & 3.00 & 813.44 & 0.00 & 25.00 & 99.40 & 3.21 & 2.36 & 16.46 \\
\hline BH5 & 8.78 & 1146 & 18.40 & 51.20 & 733.41 & 0.00 & 57.50 & 92.30 & 3.73 & 1.74 & 61.73 \\
\hline BH6 & 8.29 & 1124 & BDL & 4.10 & 719.36 & 19.00 & 34.00 & 131.35 & 7.00 & 1.52 & 133.74 \\
\hline BH7 & 7.75 & 1343 & BDL & 1.50 & 859.52 & 0.00 & 35.50 & 145.55 & 6.45 & 4.32 & 148.55 \\
\hline BH8 & 7.89 & 741 & BDL & 0.40 & 474.24 & 0.00 & 30.20 & 41.46 & 1.84 & 8.38 & 13.58 \\
\hline BH9 & 8.52 & 472 & BDL & 7.30 & 302.08 & 0.00 & 30.80 & 85.20 & 0.28 & 7.55 & 11.93 \\
\hline
\end{tabular}


Assessment of Dissolved Ions and Microbial Coliform in water from selected sites of the Upper Athi

\begin{tabular}{llllllllllll}
\hline BH10 & 8.03 & 540 & BDL & 2.20 & 345.60 & 0.00 & 25.00 & 26.03 & 2.62 & 1.98 & 16.46 \\
BH11 & 7.98 & 955 & BDL & 1.40 & 611.2 & 0.00 & 35.50 & 95.85 & 0.78 & 5.74 & 39.50 \\
R1 & 6.89 & 587 & 95.40 & 331.4 & 375.86 & 156 & 6.50 & 28.40 & 0.28 & 6.33 & 481.87 \\
R2 & 8.00 & 873 & 86.70 & 343 & 558.72 & 228 & 16.00 & 99.40 & 0.61 & 2.78 & 63.31 \\
R3 & 7.07 & 816 & 94.60 & 304 & 522.24 & 309 & 16.90 & 106.50 & 0.75 & 2.96 & 66.25 \\
R4 & 6.91 & 1202 & 80.20 & 296 & 769.38 & 297 & 20.00 & 85.30 & 2.80 & 10.74 & 74.48 \\
R5 & 7.80 & 629 & 78.30 & 327 & 402.56 & 266 & 8.40 & 81.65 & 1.02 & 7.21 & 493.80 \\
\hline Min. & 6.89 & 472 & BDL & 0.40 & 302.08 & 0.00 & 8.40 & 26.03 & 0.28 & 1.52 & 11.93 \\
Max. & 8.78 & 1568 & 95.40 & 343 & 1003 & 309 & 57.50 & 216.55 & 7.00 & 12.32 & 493.80 \\
Mean & 7.78 & 929 & 87.04 & 80.44 & 595.08 & 66.48 & 30.51 & 91.06 & 2.55 & 4.56 & 105.71 \\
SD & 0.54 & 302.90 & 7.91 & 138.07 & 193.83 & 109.85 & 12.42 & 41.25 & 1.92 & 3.23 & 136.41 \\
\hline SW: Sh & & & & & &
\end{tabular}

SW: Shallow wells, BH: Boreholes, R: River water,below detection limit (BDL)

\subsection{Heavy metals, alkali and alkaline earth metals concentration in dry and wet seasons}

Heavy metals $\mathrm{Cd}, \mathrm{Cr}, \mathrm{Cu}, \mathrm{Fe}, \mathrm{Mn}, \mathrm{Pb}, \mathrm{Zn}$, alkali and alkaline earth metals $(\mathrm{Na}, \mathrm{Ca}, \mathrm{Mg})$ in water collected in selected sites of the Upper Athi catchment area, Kenya are presented in Tables 3 and 4. Cadmium, chromium and copper levels were below detection level. Iron levels ranged from 0.03-18.40ppm in December 2011 (Table 3) and 0.33-14.125ppm in May 2012 (Table 4). The highest levels of iron were present in surface water. This could be attributed to human activities industrial effluents from steel making industries. At low levels iron is an essential in the formation of haemoglobin pigment in blood and iron deficiency leads to anaemia. However, high levels of iron could lead to iron toxicity thus causing haermosiderosis [25].

Manganese levels ranged from0.02-1.27ppm(Table 3) and 0.075-0.90 ppm (Table 4), theserange areabove the allowed limit of $0.05 \mathrm{mg} / \mathrm{Lin}$ water [26]. The high level of manganese in underground water could be due to existence of rocks containing trace amounts of manganese. Excessive intake of manganese could lead to hypertension as well as tremors and stiff-neck symptoms [27]. Lead levels ranged from 0.09-0.586 ppm(Table 3)is above the allowable limit of $0.05 \mathrm{mg} / \mathrm{L}[28]$. Lead is very toxic metal even in small amounts by causing mental retardation especially in children [29]. Zinc levels ranged from 0.06-0.25ppm (Table 3) and 0.170-1.105 ppm (Table 4). At low levels zinc is an essential mineral in metabolism and in protein synthesis [30]. Sodium, calcium and magnesium levels ranged from 19.673-116.65ppm, 18.99-201.29ppm and 0.03$18.40 \mathrm{ppm}$ respectively. Sodium levels could be attributed to sodium bearing rock minerals where sodium dissolves in water as it percolates through them to the aquifer [31],[32]. At low levels sodium is essential in nerve impulse transmission, body fluids retention as well as muscle contraction and relaxation [33], [34]. However, high intake of sodium could lead to hypertension, heart attack and stroke [35], [36]. Calcium is found in limestone while magnesium is present in magnetite rock [37]. Calcium is an essential mineral in the body in teeth and bone formation as well as neuromuscular movements. An adult's daily intake of calcium of between 700-1000mg is recommended to prevent deficiency diseases such as osteoporosis and osteomalacia [38].

Magnesium on the other hand as a co-factor, in many enzymatic reactions such as glycolysis, ATP formation transport of $\mathrm{K}, \mathrm{Na}$ and $\mathrm{Ca}$ [37]. Magnesium deficiency could lead to vasoconstriction of blood vessels, hypertension, and heart attacks among other health challenges [39], [40], [41]. A daily intake of 300$400 \mathrm{mg}$ of magnesium is recommended for an adult [38]. Therefore, both calcium and magnesium are essential elements in the body. However, it is their presence in water for laundry use that cause problems because they cause water hardness leading to more use of soap by residents of the study area as well as spoiling boilers when used in industries [42].

Table 3: Metal ions concentration in water samples from shallow wells, boreholes and rivers in the upper Athi River catchment in December 2011

\begin{tabular}{|c|c|c|c|c|c|c|c|c|c|c|c|}
\hline Sites & $\mathrm{Ca}$ & $\mathrm{Cd}$ & $\mathrm{Cr}$ & $\mathrm{Cu}$ & $\mathrm{Fe}$ & $\mathrm{Mg}$ & $\mathrm{Mn}$ & $\mathrm{Na}$ & $\mathrm{Pb}$ & $\mathrm{Zn}$ & \\
\hline SW 1 & 50.43 & BDL & BDL & BDL & 0.43 & 3.78 & BDL & 80.43 & BDL & BDL & \\
\hline SW 2 & 44.75 & BDL & 0.01 & BDL & 0.45 & 9.03 & BDL & 73.28 & 0.23 & BDL & \\
\hline SW 3 & 201.29 & BDL & BDL & BDL & 0.33 & 11.65 & BDL & 91.75 & 0.21 & 0.06 & \\
\hline SW 4 & 170.81 & BDL & BDL & BDL & 0.75 & 10.98 & BDL & 56.63 & 0.19 & BDL & \\
\hline SW 5 & 20.36 & BDL & BDL & BDL & 0.70 & 5.44 & BDL & 34.67 & 0.13 & BDL & \\
\hline BH 1 & 30.41 & BDL & BDL & BDL & 0.33 & 6.14 & BDL & 71.26 & 0.14 & BDL & \\
\hline BH 2 & 41.26 & BDL & 0.01 & BDL & 1.58 & 7.89 & BDL & 94.34 & 0.31 & 0.12 & \\
\hline BH 3 & 28.79 & BDL & BDL & BDL & 0.23 & 3.91 & BDL & 85.76 & 0.09 & BDL & \\
\hline BH 4 & & 40.32 & BDL & BDL & BDL & 0.03 & 3.64 & BDL & 78.57 & 2.64 & BDL \\
\hline BH5 & 36.68 & BDL & BDL & BDL & 1.93 & 5.01 & BDL & 90.24 & BDL & BDL & \\
\hline BH 6 & 32.97 & BDL & BDL & BDL & 0.65 & 2.72 & 0.02 & 93.66 & 0.26 & 0.07 & \\
\hline
\end{tabular}




\begin{tabular}{lllllllllll} 
BH7 & 38.21 & BDL & BDL & BDL & 0.40 & 3.32 & BDL & 101.29 & 0.14 & BDL \\
BH 8 & 26.18 & BDL & BDL & BDL & 0.47 & 2.96 & BDL & 45.36 & 0.04 & BDL \\
BH 9 & 30.22 & BDL & BDL & BDL & 0.45 & 5.30 & BDL & 19.67 & 0.11 & BDL \\
BH 10 & 44.33 & BDL & BDL & BDL & 0.35 & 5.92 & BDL & 37.46 & 0.38 & BDL \\
BH 11 & 160.75 & BDL & BDL & BDL & 0.64 & 14.39 & BDL & 51.53 & BDL & 0.25 \\
R1 & 38.47 & BDL & 0.03 & BDL & 18.4 & 7.59 & 0.25 & 116.65 & 0.12 & BDL \\
R2 & 31.45 & BDL & BDL & BDL & 4.45 & 8.46 & 1.27 & 81.93 & BDL & BDL \\
R3 & 40.66 & BDL & BDL & BDL & 4.08 & 8.01 & 0.13 & 70.18 & 0.33 & BDL \\
R4 & 39.37 & BDL & BDL & BDL & 2.11 & 9.44 & 0.94 & 85.51 & 0.17 & BDL \\
R5 & 18.99 & BDL & 0.03 & BDL & 3.43 & 5.24 & BDL & 101.23 & 0.12 & BDL \\
\hline Min. & 18.99 & BDL & 0.01 & BDL & 0.03 & 2.72 & 0.02 & 19.67 & 0.09 & 0.06 \\
Max. & 201.29 & & 0.03 & & 18.40 & 14.39 & 1.27 & 116.65 & 2.64 & 0.25 \\
Mean & 55.59 & & 0.02 & & 2.009 & 6.71 & 0.52 & 74.35 & 0.31 & 0.13 \\
SD & 52.08 & & 0.01 & & 3.98 & 3.15 & 0.551 & 25.06 & 0.59 & 0.09 \\
\hline SW: Sh & & & & & & &
\end{tabular}

SW: Shallow wells, BH: Boreholes, R: River water,below detection limit (BDL)

Table 4: Metal ions concentration in water samples from shallow wells, boreholes and rivers in the upper Athi River catchment in May 2012

\begin{tabular}{|c|c|c|c|c|c|c|c|c|c|c|c|}
\hline Sites & $\mathrm{Ca}$ & $\mathrm{Cd}$ & $\mathrm{Cr}$ & $\mathrm{Cu}$ & $\mathrm{Fe}$ & $\mathrm{Mg}$ & $\mathrm{Mn}$ & $\mathrm{Na}$ & $\mathrm{Pb}$ & $\mathrm{Zn}$ & \\
\hline SW1 & $36.63 \mathrm{BI}$ & $\mathrm{DL}$ & BDL & $\mathrm{BDL}$ & 0.33 & 2.91 & $\mathrm{BDL}$ & 64.60 & BDL & 0.44 & \\
\hline SW1 & 34.63 & BDL & BDL & & BDL & 1.22 & 7.07 & BDL & 56.40 & BDL & 0.38 \\
\hline SW3 & 185.75 & BDL & BDL & & BDL & 1.57 & 9.33 & BDL & 74.25 & BDL & 0.26 \\
\hline SW4 & 153.13 & BDL & BDL & & BDL & 0.86 & 7.90 & BDL & 39.85 & BDL & 0.39 \\
\hline SW5 & 14.75 & BDL & BDL & & BDL & 0.98 & 3.35 & 0.075 & 23.50 & BDL & 0.54 \\
\hline BH1 & $26.63 \mathrm{~B}$ & DL & BDL & BDL & 0.76 & 4.19 & BDL & 64.85 & BDL & 0.55 & \\
\hline BH2 & 36.00 & BDL & BDL & & BDL & 1.40 & 6.46 & BDL & 83.55 & BDL & 0.20 \\
\hline BH3 & $22.13 \mathrm{~B}$ & 3DL & BDL & BDL & 1.00 & 2.96 & BDL & 79.00 & BDL & 0.20 & \\
\hline BH4 & 33.50 & BDL & BDL & & BDL & 0.92 & 2.82 & BDL & 71.30 & BDL & 0.27 \\
\hline BH5 & 29.50 & BDL & BDL & & BDL & 7.54 & 3.93 & BDL & 84.75 & BDL & 0.94 \\
\hline BH6 & 26.88 & BDL & BDL & & BDL & 1.11 & 2.40 & BDL & 83.74 & BDL & 0.17 \\
\hline BH7 & 29.25 & BDL & BDL & & BDL & 0.55 & 2.96 & BDL & 88.60 & BDL & 0.24 \\
\hline BH8 & 20.25 & BDL & BDL & & BDL & 0.52 & 2.84 & BDL & 36.75 & BDL & 0.23 \\
\hline BH9 & 22.63 & BDL & BDL & BDL & 0.67 & 4.62 & BDL & 11.75 & BDL & 0.46 & \\
\hline BH10 & 36.53 & BDL & BDL & BDL & 0.73 & 5.31 & BDL & 30.45 & BDL & 0.29 & \\
\hline BH11 & 149.38 & BDL & BDL & & BDL & 0.54 & 10.96 & BDL & 43.15 & BDL & 0.43 \\
\hline R1 3 & 32.40 & BDL & BDL & & BDL & 3.63 & 6.62 & 0.13 & 102.20 & BDL & 0.27 \\
\hline R2 & 28.25 & BDL & BDL & & BDL & 3.86 & 7.25 & 0.90 & 73.95 & BDL & 0.25 \\
\hline R3 & 37.85 & BDL & BDL & BDL & 0.80 & 6.77 & 0.03 & 64.45 & BDL & 0.31 & \\
\hline R4 & 32.10 & BDL & BDL & & BDL & 14.13 & 7.62 & 0.79 & 78.15 & BDL & 1.11 \\
\hline R5 & 15.55 & BDL & BDL & BDL & 5.06 & 4.83 & 0.18 & 95.20 & BDL & 0.31 & \\
\hline Min. & 14.75 & BDL & BDL & & BDL & 0.33 & 2.82 & 0.08 & 11.75 & BDL & 0.17 \\
\hline Max. & 185.75 & BDL & BDL & & BDL & 14.13 & 10.96 & 0.90 & 102.20 & BDL & 1.11 \\
\hline Mean 2 & 47.79 & & & & 2.29 & 5.38 & 0.35 & 64.31 & & 0.40 & \\
\hline SD & 48.951 & & & & 3.27 & 2.42 & 0.386 & 24.73 & & 0.233 & \\
\hline
\end{tabular}

SW: Shallow wells, BH: Boreholes, R: River water,below detection limit (BDL)

\section{Conclusion}

Ground water is weakly alkaline due to the presence of carbonates and hydrogen carbonates present in most rock structure in the area studied. The results also indicated that ground water had high electrical conductivity due to the large amounts of total dissolved solids present. It was however noted that ground water had low turbidity since as the water percolates into the underground rocks, the rocks act as filters [43] trapping any solid particles. The colour of underground water was generally low due to the fact that the area under study only had traces of coloured transition elements.

The number of coliforms and $E$. coli was very low in ground water as compared to surface water. Most surface run-offs had high numbers of total coliforms and E. coli. From the results, boreholes recorded lower levels of coliforms than shallow wells since most boreholes are well sealed unlike shallow wells where water is 
extracted using manual methods of pulley system meaning that the wells are not always protected and are prone to flooding from surface run-off as well as contamination by containers used to draw water from the wells. Results showed that iron levels were the highest in ground water tested followed by zinc and only traces of other heavy metals. The results indicate that the underground rocks have high levels of iron and zinc.

The levels of sodium in ground water were very high and since levels of sodium combines with chlorides the water becomes unpalatable due to its salty taste. The levels of calcium and magnesium were high meaning that the water is hard. Hard water affects the amount of soap used during laundry work due to the scam formed. The levels of fluorides were a major concern. According to WHO drinking water quality guidelines water for domestic use should not exceed $1.5 \mathrm{ppm}$ fluoride levels. In Borehole BH6 located at Athi Primary school had the highest levels of fluoride ions at $9.36 \pm 0.04 \mathrm{ppm}$ which was way above the $1.5 \mathrm{ppm}$ limit set by WHO for drinking water. Children in this study area had brown teeth and with continued use of the only source of water available they may develop diseases such osteomalacia later in their lives. Results showed that levels of nitrates in ground water were generally low.

Borehole BH4 at Brookshine School had the highest levels of lead at $2.64 \pm 0.04 \mathrm{ppm}$ while sodium and iron levels were highest in river water sample R1 situated at Mbagathi River at Mombasa Road Bridge with levels of $116.65 \pm 0.02 \mathrm{ppm}$ and $18.40 \pm 0.35 \mathrm{ppm}$ respectively. Sampling site SW3 located at Ngund'u had the highest levels of calcium, magnesium and chloride. The analysis showed $201.29 \pm 0.04 \mathrm{ppm}$ calcium ions, $11.563 \pm 0.02 \mathrm{ppm}$ of magnesium ions and $226.49 \pm 0.04 \mathrm{ppm}$ of chloride ions. Levels of carbonates and bicarbonates ions were highest in borehole sample BH5 located at Athi Primary School whose levels were $64.117 \pm \mathrm{ppm}$. High levels of sulphates were found river sample R5 located at Brookshine Bridge near Brookshine School while river sample R4 located at Ongata Rongai Bridge had the highest level of nitrates at $15.68 \pm 0.01 \mathrm{ppm}$. E coli and faecal coliforms were highest in river water sample located at Mombasa road Dam wall $309 \pm 3.41 \mathrm{MPN}$.

\section{Acknowledgements}

We are grateful to Mines and Geology Department for their assistance, during the analysis of level of heavy metals, Central Water Testing Laboratory, and the Chief Chemist, Materials Testing and Research Department for allowing the useof variousfacilities in their laboratories to complete study.

\section{References}

[1] Aguide to the use of biota, sediments and water in Environmental monitoring, 2007: Edited by Deborah Chapman published by Taylor \& Francis group New York and London, $2{ }^{\text {nd }}$ Edition.

[2] Kenya Water Report, 2004: Ministry of Water and irrigation pp1-10.

[3] Al Fry et. Al, Water facts and trends, World Business Council for sustainable development, $2005,8$.

[4] Mark Fischetti, How much water do nations consume, Scientific American, 2012, 1.

[5] The 2009 Kenya Population and Housing Census volume 1C, published August 2010.

[6] Shreyasee A, Baker K, Niu J, et al, 2009. Quadriceps strength and the risk of cartilage loss and symptom progression in knee osteoarthritis 60(1) pp. 189-98

[7] Nairobi Satellite Towns Water and Sanitation Development Programme - Athi Water Services Board, Feasibility Studies for Nairobi Satellite Towns, 2003

[8] Hem, J.D., 1985. Study and Interpretation of the Chemical Characteristics of Natural Water. U.S. Geological Survey Water-Supply Paper 2254.

[9] Lide D (1992). CRC Handbook of Chemistry and Physics, $73^{\text {rd }}$ Edition, Boca raton, FL, CRC Press.

[10] Joseph V Smith, Springer Ver-lag, Feldspar Minerals Vol 1, Reviewed by R.B Ferguson, Department of earth sciences University of Manitoba, Winnipeg, New York Vol 1, 1974, p627

[11] Frape, S.K., Fritz,P., and McNutt,R.H, Water-rock interaction and chemistry of groundwater from the Canadian Shield. Geochimica et Cosmochimica Acta, v. 48, 1984, pp. 1617-1627.

[12] Thomas Harter, Basic Concepts of GroundwaterHydrologyUniversity of California, Division of Agriculture and NaturalResources, 2003, publication 8083 .

[13] Andrea G Mann*, Clarence C Tam, Craig D Higgins and Laura C Rodrigues, The association between drinking water turbidity and gastrointestinal illness: a systematic review; Journal of BMC Public Health, 7, 2007, 256

[14] Rouse R: New Drinking Water Regulations in the UK.London, Drinking Water Inspectorate; 2001.

[15] Guidelines for drinking-water quality, 2nd ed. Vol. 2. Health criteria andother supporting information.World Health Organization, Geneva, 1996.

[16] Phyllis K. Weber-Scannell and Lawrence K. Duffy, Effects of Total Dissolved Solids on Aquatic Organisms: A Review of Literature and Recommendation for Salmonid Species. American Journal of Environmental Sciences, 3(1), 2007, 1-6

[17] V.T. Patil and P. R. Patil, Physicochemical Analysis of Selected Groundwater Samples of Amalner Town in Jalgaon District, Maharashtra, India,E-Journal of Chemistry, 7(1), 2010, 111-116

[18] Sandeep Arya1, Vinit Kumar, Minakshi and Anshu Dhaka, Assessment of underground water quality: A case study of Jhansi city, Uttar Pardesh, India, International Multidisciplinary Research Journal, 1(7), 2011, 11-14

[19] Joel V. Gagliardi, and Jeffrey S. Karns, Leaching of Escherichia coliO157:H7 in Diverse Soils under Various Agricultural Management Practices; Applied and environmental microbiology, Mar. 2000, p. 877-883

[20] A.Y sangodiyin, Environmental Study on surface and ground water pollutants from abattoir effluents, Journal of Bioresource Technology, 41(3), 1992, 193-200.

[21] WHO Guidelines for Drinking-water Quality first addendum to third edition, 2006, 1, 378-380.

[22] WHO Guidelines for Drinking-water Quality first addendum to third edition, 2006, 1, 432-434

[23] WHO Guidelines for Drinking-water Quality first addendum to third edition, 2006, 1, 417-418

DOI: 10.9790/5736-100502101109 www.iosrjournals.org 108 |Page 
[24] WHO Guidelines for Drinking-water Quality first addendum to third edition, 2006, 1, 438-439.

[25] Rajappa, B., Manjappa, S \& Puttaiah, E.T., Monitoring of heavy metal concentration in groundwater of Hakinaka Taluk, India. Contemporary Engineering Sciences, 3(4), 2010, 183-190.

[26] Bruce I Dvorak, Shawn O Skipton, Wayne Woldt, Drinking water: Iron and manganese, NebGuide, University of Nebraska Lincoln, 2014, p3-4

[27] Agency for Toxic Substances and Disease Registry (ATSDR). Toxicological Profile for Manganese (Update). Draft for Public Comment. U.S. Public Health Service, U.S. Department of Health and Human Services, Atlanta, GA. 1997.

[28] Dietrich KN, Ware JH, Salganik M, Radcliffe J, Rogan WJ, Rhoads GG, Fay ME, Davoli CT, Denckla MB, Bornschein RL, Schwarz D, Dockery DW, Adubato S, Jones RL., Effect of chelation therapy on the neuropsychological and behavioral development of lead-exposed children after school entry. Pediatrics 114(1), 2004, 19-26

[29] Gregoriadou, A., Delidou, K., Dermosonoglou, D., Tsoumparis, P., Edipidi, C \& Katsougiannopoulos, B., Heavy metals in drinking water in Thessaloniki area, Greece. Proceedings of the 7th International Conference on Environmental Science and technology, Aristotle University, Ermoupolis, 2001

[30] Rajkovic, M.B., Lacnjevac, C.M., Ralevic, N.R., Stojanovic, M.D., Toskovic, D.V., Pantelic, G.K., Ristic, N.M \& Jovanic, S., Identification of metals (heavy and radioactive) in drinking water by indirect analysis method based on scale tests. Sensors, 2008, 8 , 2188-2207.

[31] United States Environmental Protection Agency (US EPA). (2012). Sodium in drinking water. Retrieved from: http://www.epa.gov/safewater/ccl/sodium.html

[32] The British Columbia Ground Water Association. Sodium in groundwater, 2002, retrieved from: http://www.llbc.leg.bc.ca/public/PubDocs/bcdocs/358319/sodium groundwater.pdf

[33] Mayo Foundation for Medical Education and Research (MFMER). (2014). Sodium: How to tame your salt habit. Retrieved from: http://www.mayoclinic.com/health/sodium/NU00284

[34] Austgen, L. (2006). The Na+ - K+ - ATPase $\quad$ (sodium pump). Retrieved from: http://www.vivo.colostate.edu/hbooks/molecules/sodium_pump.html

[35] Centers for Disease Control and Prevention (CDC). (2014). Most Americans should consume less sodium (1,500 mg/day or less) Retrieved from: http://www.cdc.gov/Features/Sodium/

[36] Shaparenko, G. (n.d.). Sodium, your health, and your drinking water. Retrieved from: http://www.aquatechnology.net/frame43251.html

[37] František Kožíšek, Health significance of drinking water calcium and magnesium, National Institute of Public Health, 2003

[38] Committee on Dietary Reference Intake. Dietary Reference Intakes for Calcium, Phosphorus, Magnesium, Vitamin D, and Fluoride. National Academy Press, Washington D.C., 1997.

[39] Rude, R.K., Magnesium deficiency: a cause of heterogenous disease in humans. J. Bone Miner.Res. 13, 1998, 749-758

[40] Innerarity, S., Hypomagnesemia in Acute and Chronic Illness. Crit. Care Nurs. Q. 23, 2000, 1-19.

[41] Saris, N.-E.L., Mervaala, E., Karppanen, H., Khawaja, J.A., Lewenstam, A., Magnesium. An update on physiological, clinical and analytical aspects. Clin. Chim. Acta, 2000, 294: 1-26.

[42] Schimatschek, H.F., Calcium and magnesium occurrence, significance and analysis. (in German). In: Grohmann, A., Hässelbarth, U., Schwerdtfeger, W. (eds.) Die Trinkwasserverordnung. 4th ed. Erich Schmidt Verlag, Berlin, 2003, 511-515.

[43] Arjen van der Wal, Understanding ground water and wells in manual drilling, PRACTICA foundation; 2008. 